\title{
The Passion of the Robbers of Šlapanice according to Bartoš, the Executioner of Brno: Between history and parody
}

Lucie Doležalová

(Charles University, Prague)

\begin{abstract}
This study presents a new edition of an intriguing opuscule entitled Passio raptorum de Slapanicz, secundum Bartoss, tortorem Brunnensem (The Passion of the Robbers of Šlapanice According to Bartoš, the Executioner of Brno), which describes the violent repression of a group of robbers tormenting the village of Šlapanice at Easter 1401 by burghers from Brno. The story is presented with the ample use of phrases from and allusions to the Gospels, creating a comic effect. Together with several other texts, it belongs among the so-called "mock-Passion narratives". It survives in a single manuscript (Prague, National Library, III E 27, ff. 61r-63r) from the end of the 15th century. The event described is not documented in any other source and the text displays several surprising features, such as a long list of (at least partly imaginary) villains, several exhortatory speeches, and a twisted validation formula. It thus remains rather enigmatic.
\end{abstract}

\section{Keywords}

medieval Latin; medieval Bible; medieval historiography; medieval parody; mock-Passion narrative; late medieval Moravia; late medieval manuscripts; late medieval Latin literature

The research leading to this study was supported by the European Regional Development Fund project KREAS, reg. no. CZ.02.1.01/0.0/0.0/16_019/0000734, as well as the Charles University project Progres Q07, "Centre for the Study of the Middle Ages." I am very grateful to Kateřina Voleková for all her help with the Old Czech transcription and interpretation, Jeff Rider for correcting my English, and the anonymous reviewers for their useful remarks. This study is for my teacher Stanislav Zajiček, a proud inhabitant of Šlapanice. 
There are many texts from the Middle Ages that have survived in a single manuscript witness whose style and contents are so specific that it is a challenge to contextualize and interpret them. This contribution presents a new edition of one such curious text, Passio raptorum de Slapanicz secundum Barthoss, tortorem Brunensem (Passion of the robbers of Šlapanice according to Bartoš, the executioner of Brno). Although this enigmatic opusculum provokes more questions than answers, it deserves scholarly attention.

At first glance, the Passio seems to be a piece of historiography, a narrative of a violent event that took place during Easter 1401, although it includes a number of surprising elements. The Passio relates that a group of robbers led by a Polish villain Kyczol arrive in Šlapanice (then a village, today a city near Brno in Moravia), settle in the local walled church, and tyrannize their neighbors, including clerics. They steal from everyone and torture all they capture, and many people run away. The burghers of Brno get together to decide what to do. Divák (i.e., Spectator or Onlooker) of Podskalí says the robbers should all be killed, and Pešek the prefect supports the idea. The nobleman Erhard of Kunštát, sent by Jošt, marquess of Moravia, arrives in Brno and asks the burghers to go ahead and kill the robbers, and so they gather an armed multitude and set off. The robbers see them coming to Šlapanice and one of them, Vlach, gives a speech to encourage the robbers, saying they should fight to win fame. Yet, Caspar the scribe responds that he is there not to fight but to record the events. The robbers get to the walls and see they are already surrounded. They address the assaulters in a friendly manner, but the burghers of Brno, rather than responding, attack them. Some robbers escape, some die in the fire set by the flaming arrows of the attackers, but most are captured. The burghers of Brno are happy and plan to raid the nearby town of Měnín, too, but they discover a barrel of wine, drink from it, and return to their homes. There follows a note about the great fame of the heroes and the infamy of the robbers and that seems to be the end. Yet, a new paragraph follows that relates that fifty-six robbers were captured and brought to Brno and describes the night before their execution. The burghers of Brno keep mocking the robbers, who promise to return all the stolen goods in a hundred years. The Brno citizens mockingly enumerate all the other robbers who are unable to come to the aid of the captives. The following day, the burghers decide to destroy the remains of the Šlapanice church, so that no other robbers can hide there.

The event is not recorded in any other source but František Hoffmann (1994 and 1996), the only person who has actually analysed the text, identified several of the characters with documented people ${ }^{1}$ and argued persuasively that the whole fits well into the context of robber practices of the time. It is also in line with other occasions of church burning in the Middle Ages, ${ }^{2}$ as well as that of the desecration of holy places. Radosław Kotecki (2012) notes the formulaic character of these desecration narratives and discusses their link to canon law, and the vocabulary of the Passio raptorum clearly fits into this context.

1 Hoffmann (1996: pp. 155-163); only those identifications that Hoffmann proposes with certainty are included in the edition apparatus.

2 For other medieval sources on burning of churches, which, however, do not form parallel in the narrative strategy to the Passio, see Raynaud (2007) or Strickland (1996). 
At the same time, the Passio includes several features that are more at home in parody and satire than in historiography, such as the wine drinking by the burghers of Brno or the pompous speeches on both sides that are out of keeping with such a petty event. The proportion of direct speech is indeed striking, and the text abounds in exhortatory and battle rhetoric to such a degree that Hoffmann considered it "almost humanistic" (1996: p. 154). Yet, no direct classical or humanistic models have been identified.

The text has another unusual and startling feature: it contains many quotations from the Bible and allusions to it; some of these citations are faithful while others are transformed and twisted. The Bible indeed permeates all medieval writing, but here it invades the plot and adds fictional elements to it - e.g., darkness comes over the earth and there is an earthquake when the robbers are captured. Most of the references are to the Passion story and the defeat of the robbers is thus explicitly likened to the sacrifice of Jesus. The parallel is striking - bloodthirsty robbers are likened to innocent figures of Christ, their attempts to save themselves as his patient resignation, and the rightfully angry burghers of Brno as the evil Jews.

The strategy of narrating a historical event through the biblical narrative of the Passion is, however, not unique to this text. There is in fact a group of nine such texts, mock-Passion narratives, surviving curiously only from England, where they seem to have been in fashion at the turn of the fourteenth century, and from Bohemia where the fashion arrived a hundred years later. ${ }^{3}$ The limitation of these texts as historical sources is clear: quotations from the Bible might have been used on the one hand because they described the given events well, or, on the other hand, because the author wanted to liken the events to those of the Bible; thus, what they tell us about the events cannot be simply trusted.

These texts lie between historiography and parody, and have received only limited attention in either context, ${ }^{4}$ except for the Passio Iudeorum Pragensium (The Passion of the Jews of Prague), which was analysed in detail, among others, by Eva Steinová (2010 and 2012) and Barbara Newman (2012). In the Passio Iudeorum, the same technique is used to describe the Prague pogrom of Easter 1389, an actual event documented in a number of sources. All the other mock-Passion narratives relate documented events as well. Thus, it is reasonable to suppose that the Passion of the robbers is based on a historical event, too.

The closest textual parallels within the group are actually between the Passio raptorum and the Passio Iudeorum (in its most detailed and intertextual version, secundum Ieškonem $\left.{ }^{5}\right) .{ }^{6}$ Yet, the Passio raptorum contains many Biblical verses that are not used in

3 Cf. Lehmann (1963: pp. 121-126, esp. 125); Doležalová (2014 and in print).

4 For examples of negative scholarly evaluation of these texts see Doležalová (in print).

$5 \quad$ Edited by Steinová (2010: pp. 18-23).

6 The closest parallel is when the attackers decide to act. In Passio Iudeorum, the passage reads: Dixit autem Ieško quadratus: "Rei sunt mortis. Et si in exterminio eorum oporteret me mori ob vindictam Iesu, non denegabo." In Passio raptorum it is: Pessko yppatus dixit: "Rei sunt mortis! Ego enim, et si oportuerit me mori cum illis, ad perdendum eos armis instructus et cuspide letus properabo [cf. Mr 26:66].” Further, the beseiged call their attackers amici and wonder why they have come in both versions [cf. Mt 22:12]. Both versions also include an allusion to rebuilding the church [cf. Mt 27:39-40, Mc 15:29] and to making a new mistake worse than the earlier one [cf. Mt 27:64]. 
any other known mock-Passion, as well as many that are included in several other texts of this type. In fact, none of the mock-Passions seems to have influenced any of the others directly. These texts shared an intertextual method, but do not seem to borrow directly from one another. ${ }^{7}$

These texts often address their own credibility in a metatextual manner. In the Passio raptorum, just before the end, there is a biblical reference to John 19:36-37 reflecting the narrative itself: Hoc autem totum factum est ut impleretur Scriptura dicens: "videbunt in quem transfixerunt." (All this happened so that the scripture is fulfilled: "They shall look on him whom they pierced.") In the Bible, the point is that the Passion had to take place so that people would see the crucified Christ with their own eyes and understand he was the true Messiah. In the Passio raptorum, however, this biblical citation is followed by the sentence:

Hic autem, qui scripsit premissa non vidit, sed manens in Brunna audivit ex fama sicque et ex auditis testimonium perhibuit, ut et vos, si vultis, credatis.

"But the one who wrote the above did not see it but remaining in Brno he heard about it through rumors, and on the basis of what he heard he gave testimony, so that you, too, if you wish, may believe."

This is a reference to John 19:35 turned upside down: it emphasizes that what is called a "testimony" is actually based on hearsay and the readers are asked to believe it if they decide to do so. Thus, on a whole, this is a reversal of the usual authentication topos, in which an author's compiling evidence and referring to eye-witness testimony argue for the trustworthiness of their account. The Gospel message, however, cannot be proven in the usual ways and Christians are asked to believe through their faith. Those who require proof are similar to doubting Thomas who was ridiculed for believing only after he had put his fingers into Christ's wound. Thus, in the Passio raptorum, reversing the authentication topos common to historiography creates another parallel to the Gospel narrative - extraordinary and impossible to prove, yet worthy of belief.

Finally, the list of other robbers is curious. František Hoffmann attempted to interpret it as referring to actual known robbers of the time. In some cases, his suggestions seem likely but in many others they are rather stretched. The list reveals its literary character, especially by including many names in rhymed couples: e.g., Duben - Buben, Kvampl Lampl, Bochovec - Rochovec, or Sapák - Kapák.

Since the manuscript in which we find the Passio raptorum was copied decades after the events the account purports to describe, the text might have originated as a mock re-writing of a piece of history, as an exercise, an attempt to amuse friends, or as a result of another momentary impulse, unconnected to the events it describes. Through its use of the literary strategy of a "mock-Passion," this opuscule can be included in the group of texts from late medieval Bohemia and fourteenth century England mentioned above, but this group had little success and influence on later literature. The mock-Passion

7 For concrete examples, see Doležalová (in print). 
might have been a passing fashion, or a literary dead-end. Later, it evoked both disapproval and disgust. In any case, these texts may be approached as belonging to a larger and exciting group of texts dependent on the Bible, written at a time when shared textual knowledge was the norm and playing with it was thus an option. ${ }^{8}$

\section{Edition}

This mock-Passion survives in a sole manuscript, Praha, Národní knihovna České republiky, III E 27, fols. $61 \mathrm{r}-63 \mathrm{r} .{ }^{9}$ It is a composite codex from late 15 th and early 16 th century including a variety of texts, none other of historiographic nature. The same scribe copied the parodic Sermo de sancto Nemine ("Sermon on Saint Nobody") ${ }^{10}$ that follows (fols. 63r-64r), and the bifolio containing the two texts might have been transmitted originally independently (fol. $64 \mathrm{v}$ is blank, except for the note Arnessto detur - "to be given to Ernest"). It was also probably written somewhat earlier than the rest of the current codex, perhaps in 1460 s or 1470 s.

The copy is not careful - there are many mistakes, dubious readings and in several points the meaning remains obscure. The present edition corrects the edition by František Šujan (1885), which included several misreadings and only very few identifications of biblical allusions. Some of Šujan's mistakes were later corrected by František Hoffmann (1996: 152-153), who, however, did not edit the whole text and made some new mistakes. The text was also published in a Czech translation in Havránek \& Hrabák \& Daňhelka (1963), which amended some but not all of Šujan's mistakes. The present edition follows the manuscript reading and notes all editorial interventions as well as the readings and emendations of Šujan and Hoffmann. Czech words were transliterated with a transcription and meaning suggested by Kateřina Voleková included in the notes. ${ }^{11}$ Sigla

ms. Praha, Národní knihovna České republiky, III E 27 (the only surviving manuscript of the text)

$\mathrm{H}$ the readings by František Hoffmann (1996)

$\check{S} \quad$ the edition by František Šujan (1885)

8 This study was supported by the European Regional Development Fund-Project "Creativity and Adaptability as Conditions of the Success of Europe in an Interrelated World" (No. CZ.02.1.01/0.0/0.0/16 _019/0000734) as well as by Progres Q07 (Centre for the Study of the Middle Ages), both carried out at the Faculty of Arts, Charles University.

9 Cf. Truhlář (1906: p. 199, č. 502) and Dragoun \& Ebersonová \& Doležalová (2021: pp. 344-346). The manuscript was digitized and is freely accessible through the database www.manuscriptorium.com [accessed 23.03. 2021].

10 Cf. Lehmann (1963: pp. 240-246); Bayless (1996: pp. 292-300) - Bayless edits the text but does not mention this manuscript (as well as a number of other extant copies).

11 Kateřina Voleková based her transcription on the index card catalogue of the Old Czech Dictionary, stored in the Department of Language Development of the Czech Language Institute of the Czech Academy of Sciences, on Svoboda (1964) and Vokabulár webový (2006-2020). 


\section{[fol. 61r]}

Passio raptorum de Slapanicz secundum Barthoss, tortorem Brunensem

In illo tempore ${ }^{12}$ egressus Kyczol ${ }^{13}$ de finibus Polonie, venit ${ }^{14}$ in Slapanicz, ubi erat ecclesia, in quam manu armata introivit ${ }^{15}$ ipse et sui complices scelerati cum illo. Cumque suggerente dyabolo sacramentis ${ }^{16}$ corporis Domini nostri Jhesu Christi, ministris ecclesie et nonnullis sanctorum reliquiis, que ubi fuerant, eiectis et ecclesiam ipsam ausu sacrilego incastellatam ${ }^{17}$ occupassent, in campum tandem publice rapine ausu ${ }^{18}$ nephando progressi ceperunt infinita maleficia per incendia, rapinas et spolia in populum terre committere ita, ut homines plurimi exulare, alii tyrannidem eorum ferre non valentes, de domiciliis propriis fugere agrosque incultos deserere cogerentur. Nec hiis contenti maleficiis sed, ut in profundum ultime desperacionis laberentur, ${ }^{19}$ dampnabilius in presbiteros, clericos, moniales, monachos, manus nocuas atroci sevicia miserunt, quosdam ex ipsis, ut pecunias extraherent, tormentis affecerunt variis, alios nudatos vestibus et ad vincula coniectos in intensissimo frigore sedere fecerunt, alios vero ferro constrinctos in carceraribus ${ }^{20}$ angustiis $^{21}$ miserabiliter tenuerunt pluraque facta nephanda patrarunt, que scribere sigillatim et pudor vetat et audire pia mens horrescit.

Videntes igitur seniores populi et consules alme ${ }^{22}$ civitatis Brunensis huiusmodi maleficia et rabiem truculentam semper in dies, congregati sunt in pretorium et inito consilio ad invicem dixerunt: "Quid facimus, quia hec crudelis malefactorum ${ }^{23}$ congregacio non modo nos et terre populum per rapinam et incursum hostilem destruit, verum eciam postposito timore in ministros dei vivi eius nomen blasphemans suam exercere tyrannidem ausu sacrilego non pavescit? Si dimittimus eam, sic omnes nos scandalum paciemur."

Unus autem ex eis, Dywak ${ }^{24}$ de Podscale nomine, cum esset quasi pontifex anni illius, prophetavit dicens: "Expedit vobis, ${ }^{25}$ ut omnes malefici et raptores pariter moriantur." 26

\footnotetext{
12 Mt 11:25 and 12:1

13 Kyczol] Kyezolt $\check{S}$

14 egressus... venit] cf. Mc 7:31

15 introivit] intravit $\check{S}$

16 sacramentis] sacramento $\check{S}$; sacramentum $H$

17 incastellatam] in castellatam $\check{S}$; a rare word with a clear meaning "surrounded by walls"; the church of Šlapanice, originally a Romanesque structure from the 12th or the 13th century, was rebuilt in early Gothic style at the turn of the 14th century and indeed fortified later in the Middle Ages; neither the walls nor the bastions have survived.

18 ausu] causa $\check{S}$

19 laberentur] labentur $\check{S}$

20 carceraribus] i.e. carceralibus (carceralis means "ad carcerem pertinens")

21 angustiis] angustis $\check{S}$

22 alme] om. $\check{S}$

23 malefactorum] maleficiorum $\check{S}$

24 Dywak] Dywak add. in marg. ms.; transcr.: Divák

25 vobis] nobis $\check{S}$

26 Unus ... moriantur] cf. Io 11:49-50
} 
Ab illo ergo die cogitaverunt interficere ${ }^{27}$ eos dicentes: "Ne forte raptores contractis viribus veniant ${ }^{28}$ et tollant locum nostrum universaque bona nostra in suos vertant usus. Scriptum est enim: 'percuciamus eos et dispergetur eorum congregacio nobis infesta, que de die in diem manus feroces mittens, opus pessimum operatur in nobis'. Hanc enim civitati nostre proximam semper habemus nobiscum, predam vero, quam rapiunt, raro vel nunquam redditam habemus. Huc usque iniuriis latrocibus ${ }^{29}$ affecti prestolabamur sub silencio pacem, que nec venit; iam necesse est, ut talibus scandalis occur[fol 61v]rentes ipsorum effrenatam ${ }^{30}$ audaciam $^{31}$ nostra conteramus potencia et statim armis correptis ad eorum exterminium procedamus."

Respondens $^{32}$ autem Pessko ${ }^{33}$ yppatus ${ }^{34}$ dixit: "Rei sunt mortis! ${ }^{35}$ Ego enim, et si oportuerit me mori cum illis, ad perdendum eos armis instructus et cuspide letus properabo.” Similiter et alii dicebant. ${ }^{36}$

Factum est autem, ${ }^{37}$ cum iam sero esset die illa, ${ }^{38}$ ecce nobilis vir Herhardus de Cunstat ${ }^{39}$ venit in Brunnam, et cum eo turba multa, ${ }^{40}$ missi a principe serenissimo Marchione Jodoco, ${ }^{41}$ qui salutari proposito civium rite pensato, eoque plurimum laudato, opem mox et operam civibus ipsis ad ea, que facienda decreverant, ${ }^{42}$ dare fideliter pollicetur. Et factum est $i t a{ }^{43}$ Cives autem predicti, quibus tantus vir opem prebebat et animum, ante sex dies

27 Ab illo ... interficere] cf. Io 11:53

28 Ne forte... veniant] Mt 27:64

29 iniuriis latrocibus] inimicis latronibus $\check{S}$; latrocibus is certainly derived from latro (thief), perhaps influenced by the variant latrocinator witnessed in Bohemia

30 effrenatam] affrenatam $\check{S}$

31 Effrenatam audaciam] cf. Cicero, Orationes (In Cat.), 1, 1, 1

32 Respondens] Priidem $\check{S}$

33 Pessko] Pessko add. in marg. ms.; Latinized Czech name Pešek; Hoffmann identifies him with Pešek Tendler, member of Brno town council (Hoffmann 1996: 155)

34 yppatus] i.e. hypatos, i, m. = praefectus, magister civium; this text seems to be the only evidence of this word in sources of Bohemian origin

35 Rei ... mortis] cf. Mt 26:66

36 Et si... dicebant] cf. Mt 26:35

37 Factum est autem] e.g. Lc 1:8

38 Cum ... illa] cf. Io 10:19

39 Erhardus de Cunsstat] Erhardus de Cunsstat add. in marg. ms.; i.e. Erhart Puška of Kunštát (d. 1415, cf. Hoffmann 1996: p. 155), or possibly Erhart of Kunštát, the Elder (d. 1406), the camerarius of Brno who acquired large possessions thanks to his support of Jobst of Moravia

40 Et ... multa] Mt 26:47

41 Jodoco] i.e. Jobst of Moravia (Jošt Moravský, ca. 1353-1411, Margrave of Moravia from 1375, also King of the Romans from 1410)

42 decreverat] devoraverant $\check{S}$

43 Et ... ita] Gn 1:7, 9, 11, 15, 30 
pasce ${ }^{44}$ collegerunt multitudinem gencium armatorum cum fustibus, lanceis, cuspidibus, clippeis ${ }^{45}$ pixidibus ${ }^{46}$ iaculis et sagittis.

Qui dum iter suum versus Slapanicz gressu celeri agerent, videntes eos raptores $c e-$ perunt contristari ${ }^{47}$ et mesti esse. ${ }^{48}$ Quidam autem ex eis, ${ }^{49}$ Wlach $^{50}$ nomine, capitaneus illorum, cum vidisset animos suorum consternatos, hac oracione ${ }^{51}$ confirmabat eos, dicens: "Obsecro, ${ }^{52}$ viri strenui, ${ }^{53}$ generis nobilitate conspicui et in rebus militaribus experti, ut adventus civium non vos terreat, ${ }^{54}$ nec animos vestros degener metus frangat, ut ponere in cordibus vestris ${ }^{55}$ hanc opinionem velitis, quod eorum iners turba voluptatibus magis civilibus quam armis inbuta posset nos tam facile suis viribus expungnare. Paterne igitur glorie memores animi deiecti consternatique vigorem resumite, muros confestim sagittis et iaculis armati ascendite, temeritatem civium simul et impetum ${ }^{56}$ fortiter retundite et hodie pro animabus vestris pungnate ${ }^{57}$ alioquin scituri $\operatorname{vos}^{58}$ et genus vestrum dedecus sempiternum merere. Si vel fuge turpis notati vicio hinc ${ }^{59}$ abscesseritis vel saltim indefensi sicut femina in dedicionem hostium venietis, hec enim dies futuri certaminis fame vestre gloriose sic illustrabit, decus, qui procul dubio ipsius certaminis gloria veneranda in spem prosperitatis vestre effusa usque ad celi sidera, laudibus extolletur populorum." ${ }^{\circ 0}$

Respondens $^{61}$ pro omnibus Caspar ${ }^{62}$ scriba dixit: "Ego ad hoc ${ }^{63}$ natus sum et ad hoc fato urgente in hunc locum veni ${ }^{64}$ non ut pugnem, sed ut scribam litteras. Obsecro, mi domine, ut si fieri potest, transeat a nobis calix iste, ${ }^{65}$ calix, inquam, presentis periculi et futuri patibuli. Spiritus quidem promptus est, caro autem omnium $^{66}$ nostrum ac vires

44 ante ... pasce] Io $12: 1$

45 clippeis] clipeis $\check{S}$

46 pixidibus] pexidibus $\check{S}$

47 Ceperunt contristari] Mc 14:19

48 ceperunt ... esse] cf. Mt 26:37

49 quidam ... eis] Lc 11:15; eis] iis $\check{S}$

50 Wlach] transcr. Vlach, i.e. Italian

51 oracione] oracio add. in marg. inf. ms.

52 obsecro] observo $\check{S}$

53 strenui] strennui $m s$.

54 Non vos terreat] cf. Iob 9:34, 13:21, 33:7

55 Ponere ... vestris] cf. Deut 11:18, Lc 9:44

56 simul et impetum] similiter impetu $\check{S}$

57 hodie ... pungnate] cf. 1 Macc 5:32

$58 \operatorname{vos}] \operatorname{nos} m s$.

59 hinc] huic $\check{S}$

60 populorum] populo $\check{S}$

61 respondens] priidem $\check{S}$; prudens $H$

62 Caspar] transcr. Kašpar

63 hoc] hec $\check{S}$

64 ego ... veni] cf. Io 18:37

65 obsecro ... iste] cf. Mt 26:39

66 omnium] omne $\check{S}$ 
[fol. 62r] adeo fragiles et infirme, ${ }^{67}$ ut tante civium multitudini resistere non possimus. Verumtamen ${ }^{68}$ non sicut nos volumus sed sicut tu vis, ${ }^{69}$ fiat voluntas tua." ${ }^{\text {70 }}$

Premissa igitur oracione firmati raptores muros ecclesie cum saxis ingentis ${ }^{71}$ et sagittis certatim $^{72}$ ascendunt et prospicientes ${ }^{73}$ per menia viderunt maximam multitudinem gencium armatarum ${ }^{74}$ stancium iam ante illos. Quibus et dixerunt: "Amici, quomodo huc ${ }^{75}$ venistis non habentes vestem nuptialem? ${ }^{76}$ Arma enim vestra iacula et sagitte, quibus instructi estis, non amicicie sed furoris vestri sunt indicia.” Nec dum illi verba sua finierant, et ecce cives Brunenses ${ }^{77}$ ceto $^{78}$ expugnabili desiderio flammantes sagittis primum et filiis pixidum loco responsi ${ }^{79}$ in hostes directis ${ }^{80}$ muros ipsos potenter invadunt, ignem porte civium ${ }^{81}$ adhibent et deinde scalis gradum prebentibus muros ecclesie apperta vi transeunt, ecclesiam capiunt, et in armis militares animos exhibentes ${ }^{82}$ in ipsos hostes iam pavore ${ }^{83}$ gelidos consternatos se unanimesque ${ }^{84}$ manus iniciunt, ab omni parte flagellis ferreis cedunt et in frontem et in latera et in tergum. Itaque subito civibus ${ }^{85}$ inpressionem facientibus hostium virtus inita ${ }^{86}$ defecerat haut omnibus pene in captivitatem redactis reliqui, ${ }^{87}$ quos $^{88}$ fuga non abstulit, in ignis et fumi thetra caligine suffocati desperatissimum spiritum perdiderunt. Ignis autem repente convalescens equos fere centum, ut fama tenet, arma multa victualia copiosa diversamque supellectilem fortem mittens aridis faucibus devoravit.

Cives autem Brunnenses, quibus primordia gloriosi certaminis ${ }^{89}$ prospere successerant, leti supra ${ }^{90}$ fidem facti de victoria continuato impetu alios raptores, qui sunt in

67 spiritus ... infirme] cf. Mt 26:41, Mc 14:38

68 Verumtamen] verum $\check{S}$

69 Verumtamen ... vis] cf. Mt 26:39

70 fiat ... tua] Mt 26:42, Lc 22:42

71 ingentis] i.e. ingentibus (either a mere scribal mistake or mistakenly declined as the second declension)

72 certatim] statim $\check{S}$

73 prospicientes] perspicientes $\check{S}$

74 armatarum] armatorum $\check{S}$

75 Quomodo huc] quo hunc $\check{S}$

76 Amici ... nuptialem] cf. Mt 22:12

77 Brunenses] i.e. Brunnenses

78 ceto] cito $e m . \check{S}$

79 responsi] response $\check{S}$

80 directis] directe $\check{S}$

81 civium] cinium $e m$. $\check{S}$; civium $H$; meaning unclear

82 exhibentes] exhibenter $\check{S}$

83 pavore] corr. ex pavodore $m s$, pavidore $\check{S}$

84 unanimesque] i.e. inanimesque

85 civibus] in $a d d . \check{S}$

86 inita] victa $\check{S}$

87 reliqui] reliquos $\check{S}$

88 virtus ... quos] in marg. $m s$.

89 gloriosi certaminis] cf. Pange lingua (Cantus Index no. 8367, Analecta hymnica, 1907, vol. 50, pp. 70-73)

90 supra] super $\check{S}$ 
Meneis alias in ${ }^{91}$ Mienyn $^{92}$ animis adhuc iram sanctam furoremque beatum spirantibus voluerunt invadere, sed, ut arbitror, non erat eis datum ${ }^{93}$ deferre, ${ }^{94}$ vas illic positum erat vino bono plenum, ${ }^{95}$ quod cum armis gravati gustassent ${ }^{96}$ bibentes ex eo fortiter et refocilato spiritu, qui in tantis laboribus pene defecerant, leti cum gaudio ad propria redierunt.

Vivite ergo felices in secula quos dextre dei presidium de hoste tam sevo triumphare constituit, et huius certaminis immortalis memoria a solis ortu usque ad occasum ${ }^{97}$ famam vestri nominis sic faciat clarescere, ut genus vestrum lucem tante glorie a nobis ${ }^{98}$ accipiens cunctis raptoribus et maleficis sit longe lateque terribile, formidabile et suspectum.

Capti sunt in hoc congressu quinquaginta sex raptores, qui dum ligatis manibus ducerentur in Brunnam viso patibulo, quod haut procul a civitate [fol. 62v] distat, exterriti sunt et facti sunt sicut mortui $i^{99}$ ita, ut cogerentur totum ${ }^{100}$ egerere, quod in unius anni spacio per ingluviem devorarant. Unde accidit, quod velum femoralium ipsorum scissum est in duas partes, a summo ${ }^{101}$ usque deorsum, ${ }^{102}$ ita ut preses preconum miraretur vehementer. ${ }^{103}$ Postea tenebre facte sunt super universam terram, ${ }^{104}$ et ex fragore armorum et tumultu ${ }^{105}$ populi terra mota est ${ }^{106}$ et multa corpora, que in lectulis dormierant ad spectaculum surrexerunt. ${ }^{107} \mathrm{Et}$ enim ${ }^{108}$ hora noctis quasi quarta precones vero et ministri iudicis collegerunt eos hospicio et illudentes eis exeverunt ${ }^{109}$ eos vestimentis eorum et induerunt eos vinculis ferreis ${ }^{110}$ et statim gallus cantavit. ${ }^{111}$ Omnes autem, qui illic aderant, moventes capita sua blasphemabant dicentes: "Wach, iniqui raptores, en ecclesia vestra, quam castrum vocastis, igne consumpta est, que vix in tribus horis reedificabitur: ${ }^{112}$

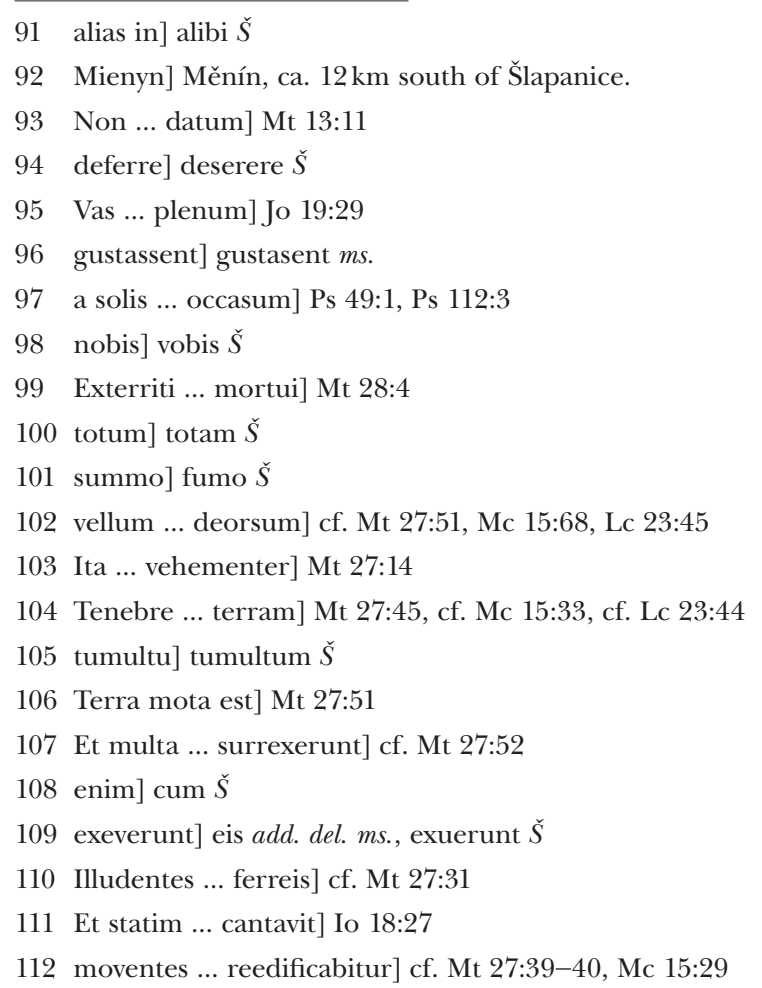


manete ergo hic, quoniam hec est domus, quam vobis in hereditatem ${ }^{113}$ elegistis. Cras enim illucescente ${ }^{114}$ die micantem tortoris gladium super vos videbitis et reddentem unicuique vestrum iuxta opera sua." 115

Et illi rogaverunt eos dicentes: "Pacienciam habete in nobis et omnia reddemus ablata." Illi autem dixerunt: "Et quando hec erunt?" Responderunt eis: "Post centum annos vel paulo plus." Illi autem indignantes dixerunt: "O iniqui, quousque in obstinata malicia permanetis? Videre enim nunc volumus Kyczolt, ${ }^{116}$ Sokol, ${ }^{117}$ Suchyczrt, ${ }^{118}$ Brzyesyna, ${ }^{119}$ Kuorka, ${ }^{120}$ Sul, ${ }^{121}$ Adam, Bycz, ${ }^{122}$ Odrole, Suchodol, Nemoy, ${ }^{123}$ Wydlak, ${ }^{124}$ Komar, ${ }^{125}$ Uhlyk, ${ }^{126}$ Otka, ${ }^{127}$ Lopata, ${ }^{128}$ Stiulik, ${ }^{129}$ Chalupnik, ${ }^{130}$ Wawak, ${ }^{131}$ Voydrzyduch, ${ }^{132}$ Metikal, ${ }^{133}$ Drwosczep, ${ }^{134}$ Sohay, ${ }^{135}$ Howencze, ${ }^{136}$ Koczwara, ${ }^{137}$ Hwyedon, ${ }^{138}$ Netozzyerz, ${ }^{139}$ Ssmrz, ${ }^{140}$

113 Quam ... hereditatem] Lev 20:24

114 illucescente] illuscente $m s$.

115 Reddentem ... sua] cf. Rev 2:23, Rev 22:12, Ps 61:13, Mt 16:27

116 Kyczolt] Kyezolt $\breve{S}$, i.e. the leader of the robbers mentioned at the beginning of the text as Kyczol (we do not transcribe because we suppose it is a Polish name)

117 Sokol] i.e. "falcon," perhaps Jan Sokol of Lamberk (Hoffmann 1996: 158).

118 Suchyczrt] transcr. Suchý črt, i.e. "dry devil," perhaps Hynek Suchý Čert of Kunštát, d. 1408 (Hoffmann 1996: 158)

119 Brzyesyna] Bryezyna $\check{S}$, Brzezyna $H$, transcr. Bř̌̌zina, i.e. "birch leaf"

120 Kuorka] transcr. Kórka, i.e. "bread crust"

121 Sul] transcr. Zúl, Hoffmann identifies him with Jan Zúl of Ostředek (d. 1404) (Hoffmann 1996: 158-159)

122 Bycz] Byč $\check{S}$, transcr. Bič, i.e. "whip”

123 Nemoy] transcr. Nemoi

124 Wydlak] transcr. Vidlák, i.e. "who works with pitchfork"

125 Komar] transcr. Komár, i.e. "gnat"

126 Uhlyk] transcr. Uhlík, i.e. "piece of coal"

127 Otka] i.e. "instrument used in ploughing for splitting clods and removing dirt from the ploughshare"

128 Lopata] i.e. "shovel"

129 Stiulik] transcr. Stulík, i.e. "water lily" (?)

130 Chalupnik] transcr. Chalupník, i.e. "cottager"

131 Wawak] transcr. Vavák, i.e. "penis"

132 Voydrzyduch] Wydrzyduch $H \check{S}$, transcr. Vydřiduch, i.e. "who blackmails or exploits someone"

133 Metikal] Metkal $\check{S}$, transcr. Mětikal, i.e. "who grubs in mud"

134 Drwosczep] transcr. Drvoščep, i.e. "sawyer"

135 Sohay] transcr. Šohaj, i.e. "young man"

136 Howencze] transcr. Hovence, i.e. "little shit"

137 Koczwara] transcr. Kocvara or Kočvara, documented name

138 Hwyedon] Hwydon $\check{S}$, transcr. Hvědon; it might be a mistake instead of Hvizdon, which is a documented name

139 Netozzyerz] transcr. Netožieř; this name is not documented

140 Ssmrz] transcr. Smrž, i.e. "mushroom" (specific type) 
Pliskota, ${ }^{141}$ Uzzwal, ${ }^{142}$ Hrzebik, ${ }^{143}$ Duben, ${ }^{144}$ Buben, ${ }^{145}$ Ssyndel, ${ }^{146}$ Homole, ${ }^{147}$ Rokoss, ${ }^{148}$ Gumpolt, Amipolt, Quampl, ${ }^{149}$ Lampl, Bochowecz, ${ }^{150}$ Rochowecz, ${ }^{151}$ Squarkarz,${ }^{152}$ Gygar, Markar, Passek, ${ }^{153}$ Klal, ${ }^{154}$ Kolda, ${ }^{155}$ Oprzal, ${ }^{156}$ Rzaksa, ${ }^{157}$ Doxa, ${ }^{158}$ Kobila, ${ }^{159}$ Sowa, ${ }^{160}$ Hassek, ${ }^{161}$ Wanyta, ${ }^{162}$ Przibik, ${ }^{163}$ Scoda, ${ }^{164}$ Sapak, ${ }^{165}$ Kapak,,${ }^{166}$ Roczenermel, ${ }^{167}$ Flug, Engenl, ${ }^{168}$ Mudowlak ${ }^{169}$ et Enndelweyn venientes liberent vos." 170

Hoc autem totum factum est ut impleretur Scriptura ${ }^{171}$ dicens: "videbunt in quem transfixerunt." ${ }^{172}$ Hic $^{173}$ autem, qui scripsit, premissa non vidit, sed manens in Brunna ${ }^{174}$ audivit

\footnotetext{
141 Pliskota] transcr. Plískota, i.e. "sleet"

142 Uzzwal] Vzzwal $\check{S}$, transcr. Užval or Uzval

143 Hrzebik] transcr. Hřebík, i.e. "nail"

144 Duben] i.e. "April"

145 Buben] i.e. "drum"

146 Ssyndel] transcr. Šindel, i.e. "shingle"

147 Homole] Homola $H \check{S}$, i.e. "cone"

148 Rokoss] transcr. Rokos, i.e. "reed"

149 Quampl] Ouampl $\check{S}$

150 Bochowecz] Bachowecz $\check{S}$, transcr. Bochovec

151 Rochowecz] transcr. Rochovec

152 Squarkarz] Sczwarkarz $\check{S}$, transcr. Škvarkář, i.e. "producer of cracklings"

153 Passek] transcr. Pašek or Pásek, i.e. "small belt"

154 Klal] transcr. Klál, i.e. "he stabbed"

155 Kolda] Hoffmann proposes to identify him with Jan Kolda of Žampach (d. ca. 1406) (Hoffmann 1996: 159)

156 Oprzal] transcr. Opršal

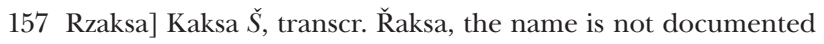

158 Doxa] Dora $\check{S}$, transcr. Doksa

159 Kobila] transcr. Kobyla, i.e. "mare"

160 Sowa] transcr. Sova, i.e. "owl"

161 Hassek] transcr. Hašek, Hoffmann suggests two different persons of this name, both witnessed in the Rosenberg books at the end of the 14th century (Hoffmann 1996: 159)

162 Wanyta] Wanita $\check{S}$, transcr. Vanita

163 Przibik] transcr. Přibík

164 Scoda] transcr. Škoda, i.e. "loss" or "harm"

165 Sapak] transcr. Sapák, i.e. "who tries to grab and shake" cf. Svoboda (1964: 133)

166 Kapak] Lapak $H \check{S}$, transcr. Kapák, i.e. "who is on his way to hell”

167 Roczenermel] Koczcuermel $\breve{S}$

168 Engenl] Engel $H$, Eigenl $\check{S}$, Gugenl $T$

169 Mudowlak] transcr. Múdovlak, i.e. "who is carrying testicles" - in old Czech material it is not documented, but there is a modern word moudivláček (Eurasian penduline tit) for a bird whose nest looks like testicles

170 videre ... vos] cf. Mt 27:49, Mc 15:36

171 hoc ... scriptura] Io 19:36

172 videbunt ... transfixerunt] videbunt iniquitatem oculi mei etc. $\check{S}$, Io 19:37, Zach 12:10

173 hic] hec $\check{S}$

174 Brunna] Bruna $\check{S}$
} 
ex fama sicque et ex auditis testimonium perhibuit, ut et vos, si vultis, credatis. ${ }^{175}$ Et facta autem hec sunt anno a nativitate Domini nostri millesimo $\mathrm{CCCC}^{\circ}$ primo, feria secunda post diem palmarum. ${ }^{176}$ [fol. 63r]

Altera autem die, que fuit tercia feria, congregati sunt seniores populi et consules civitatis ad pretorium ${ }^{177}$ et communicato consilio volentes imminentibus periculis occurrere statuerunt, ut summitates murorum, tectorum et turris, que per ignis voraginem nondum in ruinam venerant mox diruerent et usque ad fundamentum ${ }^{178}$ deponerent. Collecta igitur gencium armatorum multitudine dixerunt eis: "Ite in Slapanicz et adhibita custodia muros ipsos diruite sicut scitis, ${ }^{179}$ ne per amplius raptores illic fugiant, et fiat novissimus error peior priore. ${ }^{180}$ Illi autem abeuntes fecerunt sicut iniunctum ${ }^{181}$ erat illis. ${ }^{182}$ Etc. ${ }^{183}$

\section{Biblical references}

\begin{tabular}{|c|c|c|}
\hline Gn 1:7 & Mt 26:35 & Мс 15:29 \\
\hline Gn 1:9 & Mt 26:37 & Мc 15:36 \\
\hline Gn 1:11 & Mt 26:39 & Mc 15:68 \\
\hline Gn 1:15 & Mt 26:39 & Mc $15: 33$ \\
\hline Gn 1:30 & Mt 26:41 & Lc $1: 8$ \\
\hline Lev 20:24 & Mt 26:42 & Lc 9:44 \\
\hline Deut 11:18 & Mt 26:47 & Lc 11:15 \\
\hline Zach 12:10 & Mt 26:66 & Lc 22:42 \\
\hline Iob 9:34 & Mt 27:14 & Lc 23:44 \\
\hline Iob 13:21 & Mt 27:31 & Lc 23:45 \\
\hline Iob $33: 7$ & Mt 27:39-40 & Io $10: 19$ \\
\hline Ps 49:1 & Mt 27:45 & Io $11: 49-50$ \\
\hline Ps $61: 13$ & Mt 27:49 & Io $11: 53$ \\
\hline Ps 112:3 & Mt 27:51 (2x) & Io $12: 1$ \\
\hline Ps $136: 7$ & Mt 27:52 & Io $18: 27$ \\
\hline 1 Macc 5:32 & Mt 27:62 & Io $18: 37$ \\
\hline Mt 11:25 & Mt 27:64 (2x) & Io $19: 29$ \\
\hline Mt 12:1 & Mt 27:65 & Io $19: 35$ \\
\hline Mt 13:11 & Mt 28:4 & Io $19: 36$ \\
\hline Mt 16:27 & Mc 7:31 & Io $19: 37$ \\
\hline Mt 21:6 & Mc $14: 19$ & Rev 2:23 \\
\hline Mt 22:12 & Mc $14: 38$ & Rev 22:12 \\
\hline \multicolumn{3}{|c|}{175 qui ... credatis] cf. Io 19:35 } \\
\hline \multicolumn{3}{|c|}{176 I.e. April 4, 1401} \\
\hline \multicolumn{3}{|c|}{177 altera ... pretorium] cf. Mt 27:62 } \\
\hline \multicolumn{3}{|c|}{178 usque ad fundamentum] Ps 136:7 } \\
\hline \multicolumn{3}{|c|}{179 ite $\ldots$. scitis] cf. Mt 27:65 } \\
\hline \multicolumn{3}{|c|}{180 Et ... priore] cf. Mt 27:64 } \\
\hline \multicolumn{3}{|c|}{181 iniunctum] inunctum $\check{S}$} \\
\hline \multicolumn{3}{|c|}{182 Illi ... illis] cf. Mt 21:6 } \\
\hline 183 Etc.] amen & & \\
\hline
\end{tabular}




\section{Bibliography}

Bayless, M. (1996). Parody in the Middle Ages: The Latin Tradition. Ann Arbor: University of Michigan Press.

Doležalová, L. (2014). Passion and Passion: Intertextual Narratives in Late Medieval Bohemia between Typology, History, and Parody. In M. T. Kretschmer (Ed.), Biblical Typology as a Mode of Thinking in Medieval Historiography (pp. 245-265). Turnhout: Brepols.

Doležalová, L. (in print). Parodic Passions between England and Bohemia. In J. Čermák, \& P. Brown (Eds.), England and Bohemia in the Age of Chaucer. London: Boydell \& Brewer.

Dragoun, M., Ebersonová, A., \& Doležalová, L. (2021). Středověké knihovny augustiniánů kanovniků $v$ Tréboni a Borovanech, I: Rukopisy a inkunábule (Medieval libraries of Augustinian Canons in Třeboň and Borovany, I: Manuscripts and Incunables; pp. 344-346). Praha: Scriptorium.

Havránek, B., Hrabák, J., \& Daňhelka, J. (Eds.). (1963). Výbor z české literatury doby husitské (Anthology of Czech literature of the Hussite Period; Vol. 1, pp. 417-421, 467). Praha: Nakladatelství ČSAV.

Hoffmann, F. (1994). Bojové družiny na Moravě a v Čechách před husitskou revolucí a za revoluce (Fight troops in Moravia and Bohemia before and during the Hussite revolution). Táborský archiv, 6, 47-144.

Hoffmann, F. (1996). Pašije šlapanických loupežníků (Passion of the Robbers of Šlapanice). In L. Slezák, \& R. Vlček (Eds.), K poctě Jaroslava Marka: Sbornik praci k 70. narozeninám prof. dr. Jaroslava Marka (pp. 149-168). Praha: Akademie věd České republiky.

Kotecki, R. (2012). The Desecration of Holy Places According to Witnesses' Testimonies in the Polish-Teutonic Order Trials of the $14^{\text {th }}$ Century. In W. Sieradzan (Ed.), Arguments and Counter-Arguments. The Political Thought of the $14^{\text {th }}-15^{\text {th }}$ Centuries during the Polish-Teutonic Order Trials and Disputes (pp. 69-110). Toruń: Wydawnictwo Naukowe Uniwersytetu Mikołaja Kopernika.

Lehmann, P. (1963). Die Parodie im Mittelalter (2 ${ }^{\text {nd }}$ ed.). Stuttgart: Anton Hiersmann.

Newman, B. (2012). The Passion of the Jews of Prague: The Pogrom of 1389 and the Lessons of Medieval Parody. Church History, 81, 1-26.

Raynaud, C. (2007). L'incendie des églises: un événement? In C. Carozzi, \& H. Taviani-Crozzi (Eds.), Faire l'événement au Moyen Âge. Actes du séminaire de l'équipe de recherché Sociétés, ideologies et croyances au Moyen Âge (pp. 175-189). Aix-en-Provence: Presses universitaires de Provence.

Steinová, E. (2010). Passio Iudeorum Pragensium: Kritická edícia Pašiji pražských židov (Passio Iudeorum Pragensium: Critical edition of the Passion of the Jews of Prague). Brno: Masarykova univerzita (unpublished M.A. thesis).

Steinová, E. (2012). Jews and Christ Interchanged: Discursive Strategies in the Passio Iudeorum Pragensium. Graecolatina Brunensia, 17, 93-106.

Strickland, M. (1996). The plundering of churches: sacrilege or military expediency? In Idem, War and Chivalry: The Conduct and Perceptions of War in England and Normandy (pp. 78-97). Cambridge: Cambridge University Press.

Svoboda, J. (1964). Staročeská osobni jména a naše př́jmeni (Old Czech personal names and our surnames). Praha: Nakladatelství Československé akademie věd.

Šujan, F. (1885). Pašije šlapanických loupežníků (Passion of the robbers of Šlapanice). Sbornik historický, 3, 245-252, 301-303. 
Truhlář, J. (1906). Catalogus codicum manu scriptorum Latinorum, qui in c. r. bibliotheca publica atque Universitatis Pragensis asservantur (Vol. 2). Praha: Česká Akademie věd a umění.

Vokabulár webový. Webové hnizdo pramenů k poznáni historické češtiny (online) (Web Vocabularius. Web nest of sources for learning historical Czech). (2006-2020). Praha: Ústav pro jazyk český AV ČR, v. v. i., oddělení vývoje jazyka (verze dat 1.1.15; cit. 20.06.2020) [available from https:// vokabular.ujc.cas.cz].

Doc. Lucie Doležalová, Ph.D. / lucie.dolezalova@ff.cuni.cz

Institute of Greek and Latin Studies

Charles University, Faculty of Arts

Náměstí Jana Palacha 1/2, 11638 Praha, Czech Republic 
